Chapman University

Chapman University Digital Commons

ESI Publications

Economic Science Institute

8-18-2010

\title{
Blood Lipids, Infection, and Inflammatory Markers in the Tsimane of Bolivia
}

\author{
Sarinnapha Vasunilashorn \\ University of Southern California \\ Eileen M. Crimmins \\ University of Southern California \\ Jung KI Kim \\ University of Southern California \\ Jeff Winking \\ University of New Mexico \\ Michael Gurven \\ University of California, Santa Barbara \\ See next page for additional authors
}

Follow this and additional works at: https://digitalcommons.chapman.edu/esi_pubs

Part of the Biological and Physical Anthropology Commons, Economic Theory Commons, Ethnic Studies Commons, Latin American Studies Commons, Other Anthropology Commons, Other Economics Commons, and the Social and Cultural Anthropology Commons

\section{Recommended Citation}

Vasunilashorn, S., Crimmins, E. M., Kim, J. K., Winking, J., Gurven, M., Kaplan, H., \& Finch, C. E. (2010). Blood lipids, infection, and inflammatory markers in the Tsimane of Bolivia. American Journal of Human Biology, 22(6), 731-740. https://doi.org/10.1002/ajhb.21074

This Article is brought to you for free and open access by the Economic Science Institute at Chapman University Digital Commons. It has been accepted for inclusion in ESI Publications by an authorized administrator of Chapman University Digital Commons. For more information, please contact laughtin@chapman.edu. 


\section{Authors}

Sarinnapha Vasunilashorn, Eileen M. Crimmins, Jung KI Kim, Jeff Winking, Michael Gurven, Hillard Kaplan, and Caleb Finch

This article is available at Chapman University Digital Commons: https://digitalcommons.chapman.edu/esi_pubs/226 


\title{
Blood Lipids, Infection, and Inflammatory Markers in the Tsimane of Bolivia
}

\author{
Sarinnapha Vasunilashorn ${ }^{1},{ }^{*}$, Eileen M. Crimmins ${ }^{1}$, Jung KI Kim ${ }^{1}$, Jeff Winking ${ }^{2}$, Michael \\ Gurven $^{3}$, Hillard Kaplan ${ }^{4}$, and Caleb E. Finch ${ }^{1}$ \\ ${ }^{1}$ Davis School of Gerontology, University of Southern California, Los Angeles, California 90089 \\ ${ }^{2}$ Department of Anthropology, Texas A\&M University, College Station, Texas 77843 \\ ${ }^{3}$ Department of Anthropology, University of California, Santa Barbara, California 93106 \\ ${ }^{4}$ Department of Anthropology, University of New Mexico, Albuquerque, New Mexico
}

\begin{abstract}
Objectives-Little is known about blood cholesterol (blood-C) levels under conditions of infection and limited diet. This study examines blood-C and markers of infection and inflammation in the Tsimane of the Bolivian Amazon, indigenous forager farmers living in conditions that model preindustrial European populations by their short life expectancy, high load of infections and inflammation, and limited diets.
\end{abstract}

Methods-We use multivariate models to determine the relationships between lipid levels and markers of infection and inflammation. Adult Tsimane $(N=418$, age 20-84) were characterized for blood lipids, cells, and inflammatory markers in relation to individual loads of parasites and village region.

Results-Most of the Tsimane (60\%) carried at least one parasite species, averaging 1.3 species per person. Serum high-density lipoprotein cholesterol (HDL-C), total cholesterol (total-C), and low-density lipoprotein cholesterol (LDL-C) were below the U.S. norms and varied inversely with markers of infection and inflammation: C-reactive protein (CRP), interleukin-6 (IL-6), erythrocyte sedimentation rate (ESR), immunoglobulin (Ig) E and eosinophil count. Although no relationship of parasite load to blood-C was found, there was an association between anemia and parasite prevalence.

Conclusions-We conclude that the highly infected environment of the Tsimane is related to low levels of blood total-C, HDL-C, and LDL-C. This may suggest a potential reason why arterial disease is largely absent in the Tsimane.

The Tsimane, forager farmers of the Bolivian Amazon, are a model for aging in preindustrial human populations because of their short lifespans, high infectious morbidity, variable energy balance with high workloads, natural high fertility (Walker et al., 2008), and limited access to modern medicine. Mortality throughout the lifespan has been high; until recently, their life expectancy at birth of 42.8 years (1950-1989) approximates the demographics of 19th century European populations, Sweden, for example (Gurven et al., 2007, 2008; McDade et al., 2005).

*Correspondence to: Sarinnapha Vasunilashorn, Davis School of Gerontology, University of Southern California, 3715 McClintock Avenue, Los Angeles, California 90089, USA. vasunila@ usc.edu.

Additional Supporting Information may be found in the online version of this article. 
In addition to short life expectancies, the Tsimane also exhibit relatively low levels of blood cholesterol (blood-C) (Vasunilashorn et al., 2010; additional data presented here). Although these low lipid levels may be attributed to their typically modest diets with low saturated fat, the Tsimane also have high levels of infection. We predict that in high-infection environments there would be a potential inverse relationship between markers of infection and inflammation and blood lipid levels.

The Tsimane have a high prevalence of elevated blood C-reactive protein (CRP) at all ages (Gurven et al., 2008; McDade et al., 2007), about 25\% having a CRP value greater than 10 $\mathrm{mg} / \mathrm{dl}$, a level that indicates acute or chronic infections. In modern industrial nations with longer life expectancy and a lower burden of infection, high levels of CRP ( $33.0 \mathrm{mg} / \mathrm{dl})$ are considered indicators of cardiovascular risk (Danesh et al., 1998; Ridker et al., 2009). Tsimane reaching their 43-year life expectancy have experienced twice the average number of years cumulatively lived with high CRP ( $>3.0 \mathrm{mg} / \mathrm{dl}$ ) above the United States (Gurven et al., 2008).

Blood lipids are important mediators of host defense during the acute phase of innate immunity. Infection and inflammation typically lower blood total cholesterol (total-C) and high density lipoprotein cholesterol (HDL-C), but increase triglycerides (Esteve et al., 2005; Finch, 2007; Jahangiri et al., 2009; Khovidhunkit et al., 2004; McGullicuddy et al., 2009). Several types of infections - viral, bacterial, and parasitic — have been linked to blood lipid levels. Viral infection, as in human immunodeficiency virus (HIV) infections, are associated with lower blood levels of total-C and HDL-C (Anastos et al., 2007; Riddler et al., 2007; Rose et al., 2006), with a greater degree of dyslipidemia associated with greater immune suppression (Constans et al., 1994; Grunfeld et al., 1992; Zangerle et al., 1994). Among those infected with HIV and taking antiviral therapy, total-C, and in some cases, HDL-C was increased (Rimland et al., 2006). Experimental inflammation from bacterial endotoxin (lipopolysaccharide, LPS) induces similar dyslipidemias (McGullicuddy et al., 2009). The hypocholesterolemia and remodeling of lipoproteins during acute phase responses of innate immunity increases clearance of LPS, particularly through increased binding of LPS to HDL particles (Kitchens and Thompson, 2003; Levels et al., 2007), is one example.

Specific parasitic infections also cause dyslipidemias. A study of the Shipibo, another indigenous Amazonian group, showed an inverse correlation of HDL-C with the density of infection by three of five parasitic worm species $(N=32)$ (Wiedermann et al., 1991). Similar-sized samples from a city hospital in Chandigarh, India, showed lower HDL-C for patients with entamoebic and giardia parasites (Bansal et al., 2005). A novel hypothesis linking parasitic infection to cardiovascular disease (CVD) risk is that parasitic worms (helminths) may attenuate atherosclerosis through interactions with host defense systems (Magen et al., 2005). This relationship may involve several mechanisms. First, the helminths can suppress the host immune response through production of antiinflammatory molecules, thereby reducing the risk of CVD. Second, parasitic worms may lower the LDL levels both directly and indirectly: via regulating innate antibodies to cholesterol and interfering with host nutrition (respectively). About one third of LDL turnover is attributed to the effects of these naturally occurring antibodies to cholesterol (Alving and Wassef, 1999; CasparBauguil et al., 1999; Folcik et al., 1997). Moreover, infections potentially elicited by parasites may also regulate host lipid metabolism by stimulating a decrease in total-C levels (Doenhoff et al., 2002).

Nutrition has long been associated with blood-C levels (Clarke et al., 1997). Generally, greater intake of saturated fatty acids has been associated with higher levels of serum cholesterol (C) (Mattson et al., 1972). In subsistence populations, where food containing high saturated fats is less available than in modern societies, $\mathrm{C}$ levels are lower. For 
instance, blood-C was below the U.S. norms in several indigenous African populations and Trobiand Islanders (Expert Panel on Detection Evaluation, and Treatment of High Blood Cholesterol in Adults, 2001; Lindeberg et al., 2003; Pauletto et al., 1996; Pavan et al., 1997), and total-C levels of hunter gatherers were about $125 \mathrm{mg} / \mathrm{dl}$ (Eaton et al., 1988).

Another reason for suspecting that inflammatory markers and parasite burden may be associated with lower $\mathrm{C}$ among the Tsimane is that in populations with low energy balance and fat reserves, the burden of disease may reduce available energy further, thus affecting circulating C. Considered together, we predict that in high-infection environments there would be inverse relationships between the markers of infection and inflammation and blood lipid levels.

This study extends the previous studies on the separate effects of viral, bacterial, and parasitic infections. We considered that analyzing a combination of these types of infections could further clarify the links to blood lipids. We examined the relationships of blood lipid levels to markers of (1) inflammation [CRP and interleukin-6 (IL-6)], (2) the general burden of infection [erythrocyte sedimentation rate (ESR) and white blood cell count (WBC) and distribution], and (3) specific infections [parasite prevalence and indicators of parasite prevalence, including WBC subtype eosinophil count and immunoglobulin (Ig) E]. We also examine the body mass index (BMI), stunting, and location of village in relation to cultural influences from the nearest town, San Borja.

This article tests the hypothesis that the Tsimane, with a high infectious load, will exhibit relatively low lipid levels; thereby indicating an inverse relationship between infection and cholesterol. We hypothesize that lower levels of blood lipids will be associated with lower levels of past nutrition (i.e., lower BMI) and that blood-C levels will be higher in the more acculturated village regions located near San Borja.

\section{METHODS}

\section{Study Sample}

This study sample was drawn from the Tsimane Life History and Health Project (Gurven et al., 2008), which has been examining health across the life course since 2002. Interviews, medical examinations, and blood were collected from 17 communities across the traditional Tsimane territories. Blood and feces were sampled in 2004. This forager farmer population, of about 7,000, has low caloric intake relative to energy expenditure and consequently low BMI. The Tsimane provide a model for preindustrial human populations with limited food supply, high energy expenditure, no sanitation systems, no water treatment, and limited medical intervention (Byron, 2003; Reyes-Garcia et al., 2008; Vadez et al., 2004).

Table 1 summarizes the Tsimane adult sample $(N=418)$ for this analysis. The present study was restricted to individuals aged 20 and older (range: 20-84), with blood and fecal samples taken in 2004. Because Tsimane villages have different access to markets and medical care that may affect $\mathrm{C}$ and infections, we categorized the Tsimane communities into three geographic regions (Supporting Information Fig. 1) (Gurven et al., 2007): more acculturated villages near the town of San Borja; villages in the interior forest; and remote villages along the upper Maniqui River. These categorizations also reflect the differences in diet; for example, the Maniqui River villagers obtain more food from fish, while those in the forests obtain food from hunting. The Tsimane do not have regular exposure to modern medicines; however, those living closer to San Borja have more access to health care and richer diets, which are indicated by differences in stunting and underweight (Table 1). We include region as a covariate in the analysis to adjust for differences in access to modern medicine and diet. 


\section{Cholesterol Measures}

Blood serum was analyzed for total-C, HDL-C, and low-density lipoprotein cholesterol (LDL-C). Persons were asked to fast before coming for medical testing, but fasting was not verified. Cholesterol was stratified into high and low levels associated with adverse health outcomes in the United States (Table 2): high-risk cutoffs of HDL-C $<40 \mathrm{mg} / \mathrm{dl}$, LDL-C $>160 \mathrm{mg} / \mathrm{dl}$, and total-C $>240 \mathrm{mg} / \mathrm{dl}$. In ordinary least squares (OLSs) regressions (models described in further detail later), total-C, HDL-C, and LDL-C were used as continuous variables.

\section{Measures of Infection and Inflammation}

Blood samples were analyzed for CRP [high sensitivity (hs)-CRP], IL-6, ESR, WBC count and distribution (neutrophils, eosinophils, basophils, monocytes, and lymphocytes), and Igs A, E, G, and M. CRP is an innate immune system response to acute and chronic infections. In the U.S. and other populations with low levels of infection, CRP may also be an indicator of general systemic inflammatory responses due to chronic diseases, including atherosclerosis and diabetes. IL-6 is a cytokine with broad cellular roles in health and disease. Serum hs-CRP and IL-6 were determined from samples collected and frozen in the field, and assayed at $0.1-150.0 \mathrm{mg} / \mathrm{l}$ and $2.0-1,000.0 \mathrm{pg} / \mathrm{ml}$ (respectively) at the Tricore Reference Laboratories in Albuquerque, New Mexico using Immulite 2000 kits. The mean replicate interassay coefficient variation was $5.6 \%$ for hs-CRP and $5.8 \%$ for IL-6 (Diagnostics Products Corporation, Siemens, Deerfield, IL). Clinically normal ranges and mean values defined for U.S. populations are shown in Table 3. Using cut points employed in large-scale epidemiological studies to define low and high levels (Ferrucci et al., 2005; Seeman et al., 2004), we created an inflammatory score based on levels of both markers CRP and IL-6 (range, 0-2: 0 = high on neither, high on 1 only, high on both). An alternative score based on the highest Tsimane tertile for CRP ( $\geq 5.23 \mathrm{mg} / \mathrm{l})$ and IL-6 ( $\geq 3.02 \mathrm{pg} / \mathrm{ml})$ yielded similar results in relation to the blood-C measures; thus, the CRP-IL6 score is based on published cut points.

The ESR ( $\mathrm{mm} / \mathrm{h}$ ) gives a nonspecific measure of inflammation (Ingelsson et al., 2005; Sox and Liang, 1986). For a point of reference, we note that the mean ESR in the United States is 15 mm/h (Gillum et al., 1994; Smith and Samadian, 1994) (Table 3). In our OLS regressions, ESR is included as sex-specific quintiles (listed at the bottom of Table 4). Different levels are used for males and females due to gender variations in ESR (Piva et al., 2001).

The WBC (leukocyte) total count includes information on five types that can indicate the type of infection: eosinophils, neutrophils, leukocytes, basophils, and monocytes. The complete blood cell counts were analyzed in the field using fresh samples. Because eosinophils are elevated in some parasitic infections, the level of eosinophils was included as a categorical variable by distributing the percentages into quartiles $(Q)$ in OLS regression.

Four different immunoglobulins (Igs) were measured. IgE levels may be associated with parasitic infection and allergic reactions. IgM is the body's primary response to infection, while $\operatorname{IgG}$ is the secondary response. IgA antibodies protect body surfaces exposed to external foreign substances (e.g., ears, eyes, and nose). IgE was included in OLS regressions because of its relationship to parasite prevalence. Because of the varying sensitivity to high levels of the assays used in this project, IgE was categorized into $<2,000$ and $\geq 2,000 \mathrm{IU} / \mathrm{ml}$ (Barbee et al., 1981), and mean values are not reported (in Table 3) due to the differences in assay sensitivity.

One fresh fecal sample for each person was analyzed in the field by an experienced medical technician, who is a trained biochemist from Universidad Autónoma Gabriel René Moreno. 
The technician used a microscope to detect the presence of 17 species of parasites (Supporting Information Table 1): nine species of protozoans (Balantidium coli, Bastocystis hominis, Chilomastix mesnili, Entamoeba coli, Entamoeba hartmanni, Entamoeba histolytica, Giardia lamblia, Iodamoeba butschilii, and Trichomonas hominis) and seven worm species [roundworms Ascaris lumbricoides, Strongyloide stercoralis; whipworm Trichuris trichiura; tapeworms Hymenolepis diminuta and Taenia solium (presumably); pinworm, Enterobus vermicularis; hookworm. To determine parasite prevalence, a coverslide with a fecal smear is divided into $30 \times 30$ boxes. The medical technician scans the coverslide row by row for the presence or absence of any egg, cyst, trophozoite, or larva (depending on the species). Each coverslide is scanned for parasites twice. The first scan occurs at a 10× magnification to search for bigger parasites (e.g., Hookworm, Ascaris lumbricoides, and Balantidium coli). The second scan uses a 40× magnification for smaller parasites (e.g., protozoas, Giardia lamblia, and Entamoebas). Two slides for each fecal sample are examined: (1) sample is mixed with a $0.9 \%$ saline solution to observe movement of certain parasites (e.g., Giardia trophozoites); (2) sample is mixed with an iodine solution to observe the nuclei of amoebas.

Among these parasites, six parasites have been shown to alter blood-C: Ascaris, Trichuris, Giardia, Hookworm, Strongyloides, and Entamoeba histolytica (Bansal et al., 2005; Wiedermann et al., 1991). Dummy variables were constructed for the presence of each of the six parasites; the total number of these six C-related parasites was also examined.

\section{Covariates}

Links between blood-C levels and age, sex, and hemoglobin $(\mathrm{Hb})$ levels are also investigated (Au and Schilling, 1986; Crimmins et al., 2008a,b; Inouye et al., 1999; Mjos et al., 1977; Oguntibeju, 2003; Wilson et al., 1994). Because childhood infections can stunt growth by reallocating resources for development to combat infection, we include stunted height as an indicator of past exposure to infection (Crimmins and Finch, 2006a,b; Finch, 2007; Finch and Crimmins, 2004; Godoy et al., 2009;McDade et al., 2007, 2008). Stunting is defined using CDC guidelines (Table 1; Center for Disease Control and Prevention, 1998). Current BMI $\left(\mathrm{kg} / \mathrm{m}^{2}\right)$ is an indicator of both past and present diet and health. In the OLS regressions, BMI is included as population-derived sex-specific $Q s$. Hb, which is related to inflammation and infection as well as with lower lipid levels, was included as a categorical variable based on the sex-specific population $Q$ s. Variable-specific $Q$ ranges are listed at the bottom of Table 4 .

\section{Statistical Analyses}

OLS regression was used to determine the associations between blood-C and infection and inflammation. In predicting blood-C levels, two separate models were run for total-C, HDL$\mathrm{C}$, and LDL-C. The first models include age, sex, region, stunting, sex-specific $Q s$ of BMI, sex-specific $Q s$ of Hb, CRP-IL6 score, sex-specific quintiles of ESR, IgE, eosinophil Qs, and six parasites associated with blood-C. The second models include all the covariates from Model I, except a variable, indicating that the total number of C-related parasites was included instead of the indicators of the six individual, C-related parasites. Analyses used SAS 9.1 (SAS Institute, Inc., Cary, NC).

\section{RESULTS}

The sample (Table 1) was restricted to individuals aged 20 and more; the average age was 40 years (range, 20-84). About half resided in the river region (52\%); $19 \%$ lived in the forest villages; and 29\% lived near San Borja. About a fifth (21\%) were overweight, but few were underweight or obese (both 3\%) or stunted (4\%). 


\section{Cholesterol}

The distribution of total-C, HDL-C, and LDL-C in the Tsimane, compared with the United States, overlaps very little, with the Tsimane exhibiting lower levels for all blood-C levels (Supporting Information Figs. 2-4, respectively). We used data from persons of the same age in the U.S. National Health and Nutrition Examination Survey 2001-2006, a nationally representative study of U.S. residents, to compare the distribution of blood lipids to the Tsimane in a modern and traditional society. Compared with levels of blood-C in the United States, the mean total-C, HDL-C, and LDL-C levels among Tsimane adults are lower (Table 2).

Only one individual, a 35-year-old female, had a high-risk level of total-C (>240 mg/dl). None had elevated LDL-C estimated as $>160 \mathrm{mg} / \mathrm{dl}$. Nonetheless, about two thirds had lower HDL-C in the range representing risk for CVD $(<40 \mathrm{mg} / \mathrm{dl})$.

Mean $\mathrm{Hb}$ levels were normal. Tsimane males and females had an average $\mathrm{Hb}$ of 13 and 12 $\mathrm{g} / \mathrm{dl}$ (respectively), compared with U.S. male and female averages of 15 and $13 \mathrm{~g} / \mathrm{dl}$ (respectively) (Table 2). Half of the Tsimane women and 37\% men were anemic compared with 7\% of U.S. women and 3\% of U.S. men. Fifty-two percent of Tsimane men and $61 \%$ of women with Ascaris were anemic. All men infected with Trichuris had anemia (Supporting Information Table 1).

\section{Infection and Inflammation}

Table 3 lists the means and range for various markers of infection and inflammation in the Tsimane and United States. For many of these indicators, the Tsimane mean levels exceed the U.S. clinical norms. About $48 \%$ had elevated levels of CRP ( $\geq 3 \mathrm{mg} / \mathrm{l}), 33 \%$ had high IL-6 ( $\geq 2.68 \mathrm{pg} / \mathrm{ml})$, and nearly $25 \%$ had elevations of both CRP and IL-6. The total WBC averaged 10,442 cells $/ \mathrm{mm}^{3}$, in the upper range of the clinical norm. In contrast, mean WBC for individuals in the United States without coronary heart disease is 7,500 cells $/ \mathrm{mm}^{3}$ (Friedman et al., 1974). Neutrophils, lymphocytes, and eosinophils in the Tsimane constituted 51\%, 28\%, and 20\% of WBC (respectively) (Table 3); mean Tsimane lymphocyte percentage (28\%) is above the U.S. mean (19\%) (Horne et al., 2005). Relative to U.S. norms, eosinophils were elevated in $97 \%$ of Tsimane, with mean values about fourfold above the U.S. mean (International Still's Disease Foundation, 2008). ESR was elevated in about one quarter $(>50 \mathrm{~mm} / \mathrm{h})$, with Tsimane mean ESR values $(35.8 \mathrm{~mm} / \mathrm{h})$ twofold above the U.S. mean $(15 \mathrm{~mm} / \mathrm{h})$ (Gillum et al., 1994; Smith and Samadian, 1994).Means of all Igs exceeded the U.S. range, with a substantial proportion in the high range for $\operatorname{IgA}(23.2 \%), \operatorname{IgE}(94.2 \%), \operatorname{IgG}(69.1 \%)$, and $\operatorname{IgM}(14.9 \%)$.

The majority (60\%) of fecal samples had at least one of the six C-related parasites; two or more parasites were carried by $40 \%$ and the average number of parasite species per person was 1.3 (Table 3). The prevalence by species was Hookworm (46.2\%), Ascaris lumbricoides (17.0\%), Entamoeba histolytica (7.3\%), Strongyloides (7.1\%), Trichuris (2.9\%), and Giardia lamblia (1.6\%) (Supporting Information Table 1). These prevalence rates approximated those of other indigenous populations in South America (Baruzzi, 1970; Benefice and Barral, 1991; Chernela and Thatcher, 1989; Kaplan et al., 1980; Miranda et al., 1998; Santos et al., 1995; Tanner et al., 2009).

\section{Associations of Cholesterol with Parasitic Infection, Other Markers of Infection and Blood Inflammatory Markers}

In univariate analyses, most blood-C markers vary inversely with levels of infection (Supporting Information Table 2). Moreover, those in the highest ESR quintile had lower total-C levels than the lowest quintile; relative to no parasites, those with one or more 
parasites had lower total-C levels. However, there was no significant inverse relationship of total-C to eosinophil level (\%).

The associations of HDL-C with parasitic infection and other markers of infection and blood inflammatory markers resemble those of total-C (Supporting Information Table 2): lower HDL-C levels were associated with elevated CRP, IL-6, the composite of high CRP and IL-6, and ESR quintiles 4 and 5 (compared to quintiles 1 and 2). Additionally, lower HDL-C was associated with the prevalence of Entamoeba histolytica and Strongyloides, and having at least one of the six C-related parasites.

For LDL-C, there were no significant relationships between the indicators of infection and inflammatory markers (Supporting Information Table 2). Only elevated levels of IL-6 were significantly associated with lower LDL-C levels.

\section{Multivariate Analysis}

Markers of infection and blood inflammatory markers were generally associated with lower total-C, HDL-C, and LDL-C in multivariate analyses (Table 4). Models I and II showed an inverse relationship of total-C to elevated levels of both CRP and IL-6 $(P=0.02$ for both models), having high $\operatorname{IgE}(P<0.01$, for both models), being in the highest $Q$ of eosinophils ( $P=0.09$ and $P=0.05$ for Models I and II, respectively) and in the lowest $Q$ of $\mathrm{Hb}(P<0.01$ for both models).

Relative to Tsimane near San Borja, residents in the more remote forest region had higher total-C ( $P=0.16$ and $P=0.13$, Models I and II, respectively). Compared to individuals with BMI in $Q 2$ and $Q 3$, those in $Q 4$ had higher total-C ( $P<0.01$ for both models). These multivariate models could underestimate the total effect of parasite prevalence, which presumably affects IgE levels and eosinophils.

Age and sex were associated with total-C $(P=0.02$ for both models $)$, such that increasing age was related to higher total-C levels $(P=0.03$ and $P=0.02$ for Models I and II, respectively) and females had higher total-C than males $(P=0.02$ and $P=0.01$, respectively).

Models I and II also showed an inverse relationship between HDL-C and high levels for both CRP and IL-6 ( $P<0.01$ for both models) and being in the lowest $\mathrm{Hb} Q(P=0.03$ and $P$ $=0.05$ for Models I and II, respectively) (Table 4). Akin to total-C, there were no significant relationships of total-C to parasite prevalence (Model I). Also, similar to the total-C findings, forest residents had higher HDL-C levels compared with those living near San Borja ( $P<0.01$ for both). In comparison to individuals with BMI $Q 2$ and $Q 3$, those in $Q 1$ and $Q 4$ had higher HDL-C levels, although this relationship was significant only for $Q 1$ ( $P$ $=0.02$ for both models).

Similar to total-C and HDL-C, no relationships of LDL-C to parasite prevalence were significant (Table 4; Model I). Compared to individuals with BMI in $Q 2$ and Q3, those in $Q 4$ had significantly higher LDL-C ( $P=0.01$; Model II); in contrast to females, males had lower LDL-C levels as well $(P<0.01)$. Those residing in the forest area also had higher LDL-C than those living in San Borja $(P<0.01$; Model II).

Overall, our regression analyses show that, after adjusting for various covariates, there is a significant inverse relationship between blood lipid levels and indicators of infection and inflammation. Of note, however, is the difference in the relationships between control variables and the different lipids. For instance, sex and BMI are significantly associated with 
total-C and LDL-C, but not to HDL-C. And the village region is only associated with HDL$\mathrm{C}$ and not to total-C and LDL-C.

\section{DISCUSSION}

This study documents the high pathogen load and low blood lipids of the Tsimane and is the first to investigate multiple indicators of infection and inflammation to blood-C levels in a highly infected population. The high levels of pathogens are consistent with earlier reports on the Tsimane, in this locale (McDade et al., 2005; Gurven et al., 2007; Tanner, 2005). We found that higher levels of infection and inflammation were associated with lower levels of total-C, HDL-C, and LDL-C. These relationships remained after adjusting for other variables related to blood-C, including age, sex, nutrition (as indicated by village region and $\mathrm{BMI}$ ), past infection (stunting), and $\mathrm{Hb}$.

The lower total-C, HDL-C, and LDL-C in the Tsimane are suggestive of remodeling of the HDL-C particle during infections. In acute phase responses of innate immunity, HDL is altered ("acute phase HDL"), including a reduction of HDL-C, decreased antioxidant activity, and other structural- compositional changes and interactions with inflammatory proteins (Khovidhunkit et al., 2001, 2004). Experimentally induced inflammation by endotoxin (LPS) impairs multiple aspects of reverse $\mathrm{C}$ transport that are antiatherogenic, including efflux of blood-C from macrophages to HDL-C (McGullicuddy et al., 2009). Future studies may characterize the subclasses of HDL-C particles, particularly the remodeled particles associated with serum amyloid (SAA) that arise during acute phase responses (McGullicuddy et al., 2009). The low fat diet of the Tsimane (Byron, 2003; Reyes-Garcia et al., 2008) may also be a factor, because blood-C can be lowered by low caloric diets or fasting; we adjusted for this variability in caloric intake by including village region and BMI in the multivariate analysis. Given the interrelatedness of infection and caloric intake in determining energy balance, it is often difficult to parcel out their independent effects. The lack of fat reserves may also interact with infectious load in producing low levels of blood-C. An adaptive response to high-infectious load may be to divert energy to combat infections.

These results may provide insight into the endogenous adaptive process of energy regulation. Where the infectious burden is high, the body allocates more energy to immune responses, both invoking innate and acquired immunity, thereby reducing the available energy for other activities. The results on HDL-C are particularly interesting in this regard, as is the relationship of $\mathrm{Hb}$ to total- $\mathrm{C}$, hence suggesting that energy limitation is probably critical here. Some parasitic infections have been shown to cause anemia (e.g., Ascaris lumbricoides, Trichuris trichiura, Entamoeba histolytica) (Oguntibeju, 2003; Walter et al., 1997). This may indicate that infection reduces oxygen transport to muscles, possibly through an adaptive reallocation of energy to immune function. Similarly, presence of Ascaris and Trichuris in our Tsimane sample was associated with anemia, while the presence of Entamoeba histolytica or the total number of prevalent parasites was not.

In addition to considering indicators of infection and inflammatory markers, none of the six $\mathrm{C}$ auxotrophic parasites that has been previously associated with lower blood-C was associated with individual differences in blood-C in our study. This indirectly suggests that other types of infection, aside from parasitic infection, are important to the relationship between blood lipid levels and infection. Alternatively, the presence or absence of a specific parasite might be too crude for detecting the effect on blood-C. If most individuals have low-level parasitic infection (as shown in Supporting Information Table 1), egg or worm burden information might more reliably predict blood-C levels. We found that the number of parasites was a better predictor of blood-C, perhaps because individuals carrying a greater 
number of parasites (or polyparasitism) also may have a greater intensity of infections, which may explain the differences in effect between our measure of the total number of parasites and blood-C compared with the relationship between the presence of each individual parasite and blood-C levels. Moreover, IgE and eosinophil percentage may be a better indicator of parasitism compared with the presence/absence of parasite measure employed here; this may be especially true if parasitism is more chronic. Our study, however, does find a significant inverse relationship between high IgE levels and total-C.

Gender differences in blood-C among the Tsimane are similar to those of other populations, with males exhibiting lower total-C and LDL-C compared to females (Assman and Schulte, 1987; Kastarinen et al., 1997; Mazzarolo-Cruz et al. 1995; O'Meara et al., 2004; Stern et al. 2000). Proposed reasons that account for these sex differences include intrinsic differences in biological risk levels and acquired risks due to differences in work, lifestyle, and health aspects (Waldron, 1983). Increasing blood-C levels with age, as found for total-C in the Tsimane, have also been reported in studies of populations with low-fat diets (e.g., Tarahumara and Guatamalan Indians) (Conner et al., 1978; Mendez et al., 1962; Werner and Sareen, 1978) as well as high-fat diets (e.g., the United States) (Jacobs et al., 1980; Keys et al., 1952). Proposed determinants of this increase with age in total-C include increases in body fatness with age (Berns et al., 1989).

In the present study, modern medications are unlikely to be an important factor, because until recently these Tsimane populations have had almost no access to modern medicine. While it is still very limited, it has increased within the past 10 years. Ethnobotanic knowledge may also be an important variable in these local differences: McDade et al. 2007 showed that the level of maternal ethnobotanic knowledge correlated with Tsimane child growth and health and could have been similarly employed more by those living in the more remote villages of the present study, as suggested by a moderate correlation between mother's ethnobotanic knowledge and village distance to the nearest commercial center $(0.49, P<0.001)$.

This current study has several strengths, particularly the availability of multiple markers of immune activation and inflammation and parasite prevalence, in addition to evaluations on blood-C levels, in a unique population. This study sample gave a unique opportunity to investigate the relationship between living in a high infection environment and blood-C levels within an indigenous population. While several studies have examined the relationship of markers of infection and immune activation to blood-C or the relationship between parasites and blood-C, none has examined the relationships among all of these indicators in a well-defined indigenous population.

We also note some limitations. These cross-sectional observations without a longitudinal component do not allow us to evaluate causal effects. We do not know whether specific infections result in activation of the inflammatory cascade, which in turn may affect bloodC. Another caveat is the uncertainty of fasting in the blood samples. The observed low LDL$\mathrm{C}$ thus might be even lower if fasting were complete. When we categorize the individuals into those with blood samples drawn in the morning (before 12 p.m.- -samples likely reflecting fasting conditions) and in the afternoon (at or after 12 p.m.- - samples less likely to reflect fasting conditions), we find no significant differences in total-C, HDL-C, nor LDL-C levels $(P=0.16,0.69$, and 0.13 , respectively). Also, the limited number of cases and the nonsignificant results for LDL-C suggests that the reported relationships of the presence of the three parasites (Ascaris, Strongyloides, and Hookworm) to LDL-C reflects a true association (power values of 91, 99, and 97\%, respectively), but there does not appear to be enough power to estimate the relationships of LDL-C to other variables. Lastly, our use of fecal smears to determine parasite prevalence may result in an underestimate of the actual 
parasite load. Depending on the location of the stool from which the slide smear sample was taken, traces of a prevalent parasite may not have been detected. This would alter the observed relationships. Using Percoll gradients to concentrate parasites in a small sample of Tsimane samples, we observed about one additional parasite species per person above the fecal smears. Another limitation of our measure of parasite prevalence is the single fecal sample, which may give an inaccurate parasite prevalence. For a subsample $(N=56)$ with two fecal samples taken on different dates in 2004, the majority (70\%) showed no difference in the total number of $\mathrm{C}$-associated parasites.

Variations in blood-C show about 35\% heritability in North America, Europe, and Japan (Dahlen et al., 1983; Hegele et al., 1997; Heller et al., 1993; Rao et al., 1982). Genetic heritabilities for Amerindians enrolled in the Strong Heart Study (North et al., 2003) and among Mexican Americans (Mitchell et al., 1996) were also found for HDL-C. Among Yucatan Mayans, polymorphisms in the apolipoprotein AI/CIII/AIV gene cluster were associated with a lowering of total-C (Ahn et al., 1991). Futhermore, in Mexican Americans of the San Antonio Family Heart Study, the additive effects of both shared genes and environments contributed to an inverse relationship between HDL-C and triglycerides (Mahaney et al., 1995), suggesting that gene/environment interactions underscore a substantial amount of the variation in blood lipid levels. Genetic analysis for the Tsimane is planned, and based on previous studies, we expect that accounting for the effects of genetic differences, the variance in blood-C levels due to some factors (e.g., BMI) will be slightly reduced.

In summary, we conclude that the highly infected environment of the Tsimane is related to low levels of blood total-C, HDL-C, and LDL-C. Our recent study examines other vascular risk factors and potentially related health outcomes, which have provided more insight as to the immediate and long-term consequences of living under such highly infected environmental conditions (Gurven et al., 2009). Decreases in ankle brachial index, a measure for peripheral arterial disease (PAD) diagnosis, was associated with higher ESR and diastolic blood pressure, suggesting a relationship between cardiovascular risk factors, PAD, and infection. Moreover, higher ESR is also associated with lower SBP and DBP in the Tsimane. This study indicates that arterial disease is largely absent in the Tsimane, and our present study indicates that one mechanism promoting this would be low levels of blood-C and disease-mediated reductions in blood-C. Moreover, the Tsimane could be an important population for evaluating the hypothesis that parasitic helminths attenuate atherosclerosis and CVD risk through interactions with host-defense systems (Magen et al., 2005). The present samples allow further analysis of a population with limited access to antibiotics that can alter inflammatory processes of atherogenesis. The Tsimane thus represent a unique and fleeting opportunity to study relationships of infection, inflammation, and aging-related conditions under preindustrial conditions similar to those of our ancestral past in the absence of modern medicine.

\section{Supplementary Material}

Refer to Web version on PubMed Central for supplementary material.

\section{Acknowledgments}

Grant sponsor: National Institute on Aging; Contract grant numbers: RD1AG024119-01, P30AG17265, R21AG031988, T32AG0037; Grant sponsor: National Science Foundation; Contract grant number: BCS-0422690; Grant sponsors: Keck Foundation, USC Oakley Fellowship Fund, Ziegler Fund, and the Ellison Medical Foundation. 


\section{LITERATURE CITED}

Ahn YI, Valdez R, Reddy AP, Cole SA, Weiss KM, Ferrell RE. DNA polymorphisms of the apolipoprotein AI/CIII/AIV gene cluster influence plasma cholesterol and triglyceride levels in the Mayans of the Yucatan Peninsula, Mexico. Hum Hered. 1991; 41:281-289. [PubMed: 1778603]

Alley DE, Seeman TE, Kim JK, Karlamangla A, Hu P, Crimmins EM. Socioeconomic status and Creactive protein levels in the US population: NHANES IV. Brain Behav Immun. 2006; 20:495-504.

Alving CR, Wassef NM. Naturally occurring antibodies to cholesterol: a new theory of LDL cholesterol metabolism. Immunol Today. 1999; 20:362-366. [PubMed: 10431156]

Anastos K, Lu D, Shi Q, Tien PC, Kaplan RC, Hessol NA, Cole S, Vigen C, Cohen M, Young M, Justman J. Association of serum lipid levels with HIV serostatus, specific antiretroviral agents, and treatment regimens. J Acquir Immune Defic Syndr. 2007; 45:34-42. [PubMed: 17460470]

Assman G, Schulte H. The Prospective Cardiovascular Munster Study prevalence and prognostic significance of hyperlipidemia in men with systemic hypertension. Am J Cardiol. 1987; 59:9-17.

Astor BC, Muntner P, Levin A, Eustace JA, Coresh J. Association of kidney function with anemia. Arch Intern Med. 2002; 162:1401-1408. [PubMed: 12076240]

Au YPT, Schilling RF. Relationship between anemia and cholesterol metabolism in 'sex-linked anemic' (gene symbol, sla) mouse. Biochim Biophys Acta. 1986; 883:242-246. [PubMed: 2874831]

Bansal D, Bhatti HS, Seghal R. Altered lipid parameters in patients infected with Entamoeba histolytica, Entamoeba dispar and Giardia lamblia. Br J Biomed Sci. 2005; 62:63-65. [PubMed: 15997878]

Barbee RA, Halonen M, Lebowitz M, Burrows B. Distribution of IgE in a community population sample: correlations with age, sex, and allergen skin test reactivity. J Allergy Clin Immunol. 1981; 68:106-111. [PubMed: 7251998]

Baruzzi RG. Contribution to the study of toxoplasmosis epidemiology. Serologic survey among the Indians of the Upper Xingu River, central Brazil. Rev Inst Med Trop Sao Paulo. 1970; 12:93-104. [PubMed: 5517820]

Benefice E, Barral H. Differences in life style and nutritional status between settler and Siona-Secoya Indians living in the same Amazonian Milieu. Ecol Food Nutr. 1991; 25:1-16.

Berns MAM, de Vries JHM, Katan MB. Increase in body fatness as a major determinant of changes in serum total cholesterol and high density lipoprotein cholesterol in young men over a 10-year period. Am J Epidemiol. 1989; 130:1109-1122. [PubMed: 2589304]

Byron, EM. University of Florida, Ph.D. Dissertation. 2003. Market integration and health: the impact of markets and acculturation on the self-perceived morbidity, diet, and nutritional status of the Tsimane' Amerindians of lowland Bolivia.

Carroll MD, Lacher DA, Sorlie PD, Cleeman JI, Gordon DJ, Wolz M, Grundy SM, Johnson CL. Trends in serum lipids and lipoproteins of adults, 1960-2002. JAMA. 2005; 294:1773-1781. [PubMed: 16219880]

Caspar-Bauguil S, Tcaczuk J, Haure MJ, Durand M, Alcouffe J, Thomsen M, Salvayre R, Benosit H. Mildly oxidized low density lipoproteins decrease early production of interleukin-2 and nuclear factor kB binding to DNA in activated T-lymphocytes. Biochem J. 1999; 337:269-274. [PubMed: 9882624]

Centers for Disease Control and Prevention. Pediatric nutrition surveillance, 1997 full report. Atlanta: U.S. Department of Health and Human Services, Centers for Disease Control and Prevention; 1998.

Chernela JM, Thatcher WE. Comparison of parasite burdens in two native Amazonian populations. Med Anthropol. 1989; 10:279-285. [PubMed: 2747457]

Clarke R, Frost C, Collins R, Appleby R, Peto R. Dietary lipids and blood cholesterol: quantitative meta-analysis of metabolic ward studies. BMJ. 1997; 11:112-117. [PubMed: 9006469]

Conner WE, Cerqueira MT, Connor RW, Wallace RB, Malinow MR, Casdorph HR. The plasma lipids, lipoproteins, and diet of Tarahumara Indians of Mexico. Am J Clin Nutr. 1978; 31:11311142. [PubMed: 665563] 
Constans J, Pellegrin JL, Peuchant E, Dumon MF, Pellegrin I, Sergeant C, Simonoff M, Brossard G, Barbeau P, Fleury H, Cler M, Leng B, Conri C. Plasma lipids in HIV-infected patients: a prospectgive study in 95 patients. Eur J Clin Invest. 24:416-420. [PubMed: 7957495]

Crimmins E, Vasunilashorn S, Kim JK, Alley D. Biomarkers related to aging in human populations. Adv Clin Chem. 2008a; 46:161-216. [PubMed: 19004190]

Crimmins EM, Vasunilashorn S, Kim JK, Hagedorn A, Saito Y. A comparison of biological risk factors in two populations: the United States and Japan. Popul Dev Rev. 2008b; 34:457-482. [PubMed: 19421428]

Crimmins EM, Finch CE. Commentary: do older men and women gain equally from improving childhood conditions? Int J Epidemiol. 2006a; 35:1270-1271. [PubMed: 16980313]

Crimmins EM, Finch CE. Infection, inflammation, height, and longevity. Proc Natl Acad Sci USA. 2006b; 103:498-495. [PubMed: 16387863]

Danesh J, Collins R, Appleby P, Peto T. Association of fibrinogen, C-reactive protein, albumin, or leukocyte count with coronary heart disease: Meta-analyses of prospective studies. JAMA. 1998; 279:1477-1482. [PubMed: 9600484]

Dahlen G, Ericson C, de Faire U, Iselius L, Lundman T. Genetic and environmental determinants of cholesterol and HDL-cholesterol concentrations in blood. Int J Epidemiol. 1983; 12:32-35. [PubMed: 6682407]

DiaMed EuroGen. IgE Microtiterstrip ELISA kit. Turnhour, Belgium: DiaMed EuroGen; 2007.

Doenhoff MJ, Stanley RG, Griffiths K, Jackson CL. An anti-atherogenic effect of Schistoma mansoni infections in mice associated with a parasite-induced lowering of blood total cholesterol. Parasitology. 2002; 125:415-421. [PubMed: 12458825]

Eaton SB, Konner M, Shostak M. Stone agers in the fast lane: chronic degenerative diseases in evolutionary perspective. Am J Med. 1988; 84:739-749. [PubMed: 3135745]

Esteve E, Ricart W, Fernández-Real JM. Dyslipidemia and inflammation: an evolutionary conserved mechanism. Clin Nutr. 2005; 24:16-31. [PubMed: 15681098]

Expert Panel on Detection Evaluation, and Treatment of High Blood Cholesterol in Adults. Executive summary of the third report of The National Cholesterol Education Program (NCEP) Expert Panel on Detection, Evaluation, and Treatment of High Blood Cholesterol in Adults (Adult Treatment Panel III). JAMA. 2001; 285:2486-2497. [PubMed: 11368702]

Ferrucci L, Corsi A, Lauretani F, Bandinelli S, Bartali B, Taub DD, Guralnik JM, Longo DL. The origins of age-related proinflammatory state. Blood. 2005; 105:2294-2299. [PubMed: 15572589]

Finch, CE. The biology of human longevity. Burlington, MA: Elsevier; 2007. p. 234-294.

Finch CE, Crimmins EM. Inflammatory exposure and historical changes in human life-spans. Science. 2004; 305:176-179.

Folcik VA, Aamir R, Cathcart MK. Cytokine modulation of LDL oxidation by activated human monocytes. Arterioscl Thromb Vasc Biol. 1997; 17:1954-1961. [PubMed: 9351359]

Friedman GD, Klatsky AL, Siegelaub AB. The leukocyte count as a predictor of myocardial infarction. N Engl J Med. 1974; 290:1275-1278. [PubMed: 4827627]

Gillum RF, Mussolino ME, Makuc DM. Erythrocyte sedimentation rate and coronary heart disease: the NHANES I epidemiologic follow-up study. J Clin Epidemiol. 1994; 48:353-361. [PubMed: 7897457]

Godoy R, Nyberg C, Eisenberg DT, Magvanjav O, Shinnar E, Leonard WR, Gravlee C, Reyes-García V, McDade TW, Huanca T, Tanner S. Bolivian TAPS Study Team. Short but catching up: statural growth among native Amazonian Bolivian children. Am J Hum Biol. 2009; 22:336-347. [PubMed: 19844899]

Grunfeld C, Pang M, Doerrler W, Sigenaga JK, Jensen P, Feingold KR. Lipids, lipoproteins, triglyceride clearance, and cytokines in human immunodeficiency virus infection and the acquired immunodeficiency syndrome. J Clin Endocrinol Metab. 1992; 74:1045-1052. [PubMed: 1373735]

Gurven M, Kaplan H, Supa AZ. Mortality experience of Tsimane Amerindians of Bolivia: regional variation and temporal trends. Am J Hum Biol. 2007; 19:276-298.

Gurven M, Kaplan H, Winking J, Finch C, Crimmins EM. Aging and inflammation in two epidemiological worlds. J Gerontol A Biol Sci Med Sci. 2008; 63:196-199. [PubMed: 18314457] 
Gurven M, Kaplan H, Winking J, Rodriguez DE, Vasunilashorn S, Kim JK, Finch C, Crimmins E. Inflammation and infection do no promote arterial aging and cardiovascular disease among lean horticulturalists. PLoS One. 2009; 4:e36590.

Hegele RA, Connelly PW, Hanley AJF, Sun F, Harris SB, Zinman B. Common genomic variants associated with variation in plasma lipoprotein in aboriginal Canadians. Arterioscler Thromb Vasc Biol. 1997; 17:1060-1066. [PubMed: 9194755]

Heller DA, de Faire U, Pedersen NL, Dahlen G, McClearn GE. Genetic and environmental influences on serum lipid levels in twins. N Engl J Med. 1993; 328:1150-1156. [PubMed: 8455681]

Horne BD, Anderson JL, John JM, Weaver A, Bair TL, Jensen KR, Renlund DG, Muhlestein JB. for the Intermountain Heart Collaborative (IHC) Study Group. Which white blood cell subtypes predict increased cardiovascular risk? J Am Coll Cardiol. 2005; 45:1638-1643. [PubMed: 15893180]

Hsu C-Y, McCulloch CE, Curhan GC. Epedemiology of anemia associated with chronic renal insufficiency among adults in the United States: results from the Third National Health and Nutrition Examination Survey. J Am Soc Nephrol. 2002; 13:504-510. [PubMed: 11805181]

Ingelsson E, Ärnlöv J, Sundström J, Lind L. Inflammation, as measured by erythrocyte sedimentation rate, is an independent predictor for the development of heart failure. J Am Coll Cardiol. 2005; 45:1802-1806. [PubMed: 15936609]

Inouye M, Mio T, Sumino K. Glycated hemoglobin and lipid peroxidation in erythrocytes of diabetic patients. Metabolism. 1999; 48:205-209. [PubMed: 10024083]

[Accessed January 21, 2008] International Still's Disease Foundation website. Available: http:// www.stillsdisease.org/lab_tests/cbc

Jacobs DR Jr, Hunninghake DB, Dempsey M, Taylor HL, Kuba K, Leupker RV, Dawson EA, Frantz ID Jr, Hanna P. Blood lipids and lipoproteins in a Minnesota urban population. J Chron Dis. 1980; 33:395-406. [PubMed: 7380974]

Jahangiri A, de Beer MC, Noffsinger V, Tannock LR, Ramaiah C, Webb NR, van der Westhuyzen DR, de Beer FC. HDL remodeling during the acute phase response. Arterioscler Throm Vasc Biol. 2009; 29:261-267.

Kannel WB, Vasan RS, Keyes MJ, Sullivan LM, Robins SJ. Usefulness of triglyceride-high-density lipoprotein versus the cholesterol-high-density lipoprotein ratio for predicting insulin resistance and cariometabolic risk (from the Framingham Offspring Cohort). Am J Cardiol. 2008; 101:497501. [PubMed: 18312765]

Kaplan JE, Larrick JW, Yost J, Farrell L, Greenberg HB, Herrmann KL, Sulzer AJ, Walls KW, Pederson L. Infectious disease patterns in the Waorani, an isolated Amerindian population. Am J Trop Med Hyg. 1980; 29:298-312. [PubMed: 7369449]

Kastarinen MJ, Nissinen AM, Vartiainen EA, Jousilahti PJ, Korhonen HJ, Puska PM, Tuomilehto JO. Blood pressure levels and obesity trends in hypertensive and normotensive Finnish population from 1982 to 1997. J Hypertens. 2000; 18:255-262. [PubMed: 10726710]

Keys A, Fidanza F, Scardi V, Bergami G. The trend of serum cholesterol levels with age. Lancet. 1952; 2:209-210. [PubMed: 14939889]

Khovidhunkit W, Kim M-S, Mmon RA, Shigenaga JK, Moser AH, Feingold KR, Grunfeld C. Effects of infection and inflammation on lipid and lipoprotein metabolism: mechanisms and consequences to the host. J Lipid Res. 2004; 45:1169-1196. [PubMed: 15102878]

Khovidhunkit W, Shigenaga JK, Moser AH, Feingold KR, Grunfeld C. Cholesterol efflux by acutephase high density lipoprotein: role of lecithin:cholesterol acyltransferase. J Lipid Res. 2001; 42:967-975. [PubMed: 11369805]

Kitchens RL, Thompson PA. Impact of sepsis-induced changes in plasma on LPS interactions with monocytes and plasma lipoproteins: roles of soluble CD14, LBP, and acute phase lipoproteins. J Endotoxin Res. 2003; 9:113-118. [PubMed: 12803885]

Levels JHM, Pajkrt D, Schultz M, Hoek FJ, van Tol A, Meijers JCM, van Deventer SJH. Alterations in lipoprotein homeostasis during human experimental endotoxemia and clinical sepsis. Biochim Biophys Acta. 2007; 1771:1429-1438. [PubMed: 17980169] 
Lindeberg S, Ahren B, Nilsson A, Cordain L, Nilsson-Ehle P, Vessby B. Determinants of serum triglycerides and high-density lipoprotein cholesterol in traditional Trobriand Islanders: the Kitava Study. Scand J Clin Lab Invest. 2003; 63:175-180. [PubMed: 12817903]

[Accessed January 21, 2008] Lymphomation website. Available: http://www.lymphomation.org/testsimmunoglobulins.htm\#IgA

Magen E, Borkow G, Bentwich Z, Mishal J, Scharf S. Can worms defend our hearts? Chronic helminthic infections may attenuate the development of cardiovascular diseases. Med Hypoth. 2005; 64:904-909.

Mahaney MC, Blangero J, Comuzzie AG, VandeBerg JL, Stern MP, MacCluer JW. Plasma HDL cholesterol, triglycerides, and adiposity: a quantitative genetic test of the Conjoint Trait Hypothesis in the San Antonio Family Heart Study. Circulation. 1995; 92:3240-3248. [PubMed: 7586310]

Malik S, Wong ND, Franklin S, Pio J, Fairchild C, Chen R. Cardiovascular disease in U.S. patients with metabolic syndrome, diabetes, and elevated C-reactive protein. Diab Care. 2005; 28:690-693.

Mattson FH, Erikson BA, Kligman AM. Effect of dietary cholesterol on serum cholesterol in man. Am J Clin Nutr. 1972; 25:589-594. [PubMed: 5064235]

Mazzarolo-Cruz HM, Cruz J, Milon D Jr. Dyslipidaemias in white normotensive subjects and in white patients treated for essential hypertension. Rev Hosp Clin Fac Med Sao Paulo. 1995; 50:326-329. [PubMed: 8731254]

McDade TW, Leonard WR, Burhop J, Reyes-GarciáVadez V, Huanca T, Godoy RA. Predictors of Creactive protein in Tsimane' 2 to 15 year-olds in lowland Bolivia. Am J Phys Anthr. 2005; 128:906-913.

McDade TW, Reyes-Garcia V, Blackinton P, Tanner S, Huanca T, Leonard WR. Maternal ethnobotanical knowledge is associated with multiple measures of child health in the Bolivian Amazon. Proc Natl Acad Sci USA. 2007; 104:6134-6139. [PubMed: 17389376]

McDade TW, Reyes-García V, Tanner S, Huanca T, Leonard WR. Maintenance versus growth: investigating the costs of immune activation among children in lowland Bolivia. Am J Phys Anthropol. 2008; 136:478-484. [PubMed: 18383156]

McGullicuddy FC, de la Llera Moy M, Hinkle CC, Joshi MR, Chinquoine EH, Billheimer JT, Rothblat GH, Reilly MP. Inflammation impairs reverse cholesterol transport in vivo. Circulation. 2009; 119:1135-1145. [PubMed: 19221221]

[Accessed January 21, 2008] Medicine Net website. Available: http://www.medterms.com/script/main/ art.asp? articlekey $=515737$

Mendez J, Tejada C, Flores M. Serum lipid levels among rural Guatamalan Indians. Am J Clin Nutr. 1962; 10:403-409. [PubMed: 14472560]

Miranda RA, Xavier FB, Menezes RC. Parasitismo intestinal em uma aldeia indígena Parakanã, sudeste do Estado do Pará, Brasil (Intestinal parasitism in a Parakanã indigenous community in southwestern Pará state, Brasil). Cadernos de Saúde Pública. 1998; 14:507-511.

Mitchell BD, Kammerer CM, Blangero J, Mahaney MC, Rainwater DL, Dyke B, Hixson JE, Henkel RD, Sharp M, Comuzzie AG, VandeBerg JL, Stern MP, MacCluer JW. Genetic and environmental contributions to cardiovascular risk factors in Mexican Americans. The San Antonio Family Heart Study. Ciculation. 94:2159-2170.

Mjos OD, Thelle DS, Forde OH, Vik-Mo H. Family study of high density lipoprotein cholesterol and the relation to age and sex. The Tromso Heart Study. Acta Med Scand. 1977; 201:323-329. [PubMed: 192048]

North KE, Howard BV, Welty TK, Best LG, Lee ET, Yeh JL, Fabsitz RR, Roman MJ, MacCluer JW. Genetic and environmental contributions to cardiovascular disease risk in American Indians: the strong heart family study. Am J Epidemiol. 2003; 157:303-314. [PubMed: 12578801]

O’Meara JG, Kardia SL, Armom JJ, Brown CA, Boerwinkle E, Turner ST. Ethnic and sex differences in the prevalence, treatment, and control of dyslipidemia among hypertensive adults in the GENOA study. Arch Int Med. 2004; 164:1313-1318. [PubMed: 15226165]

Oguntibeju OO. Parasitic infestation and anaemia: the prevalence in a rural hospital setting. J Indian Acad Clin Med. 2003; 4:210-212. 
Pauletto P, Puato M, Caroli MG, Casiglia E, Munhambo AE, Cazzolato G, Bittolo Bon G, Angeli MT, Calli C, Pessina AC. Blood pressure and atherogenic lipoprotein profiles of fish-diet and vegetarian villagers in Tanzania: the Lugalawa study. Lancet. 1996; 348:784-788. [PubMed: 8813985]

Pavan L, Casiglia E, Pauletto P, Batista SL, Ginocchio G, Kwankam MMY, Biasin R, Mazza A, Puato M, Russo E, Pessina AC. Blood pressure, serum cholesterol and nutritional state in Tanzania and in the Amazon: comparison with an Italian population. J Hypertens. 1997; 15:1083-1090. [PubMed: 9350582]

Piva E, Sanzari MC, Servidio G, Plebani M. Length of sedimentation reaction in undiluted blood (erythrocyte sedimentation rate): variations with sex and age and reference limits. Clin Chem Lab Med. 2001; 39:451-454. [PubMed: 11434396]

Rao DC, Laskarzewski PM, Morrison JA, Khoury P, Kelly K, Wette R, Russell J, Glueck CJ. The Cincinnati Lipid Research Clinic Family Study; Cultural and biological determinants of lipids and lipoprotein concentration. Am J Hum Genet. 1982; 34:888-903. [PubMed: 7180846]

Reyes-Garcia V, Vadez V, Godoy R, Huanaca T, Leoanrd W, McDade T, Tanner S. Non-market returns to traditional and modern human capital: nutritional status in a native Amazonian society. $\mathrm{J}$ Dev Stud. 2008; 44:206-221.

Riddler SA, Li X, Chu H, Kingsley LA, Dobs A, Evans R, Palella F, Visscher B, Chmiel JS, Sharrett AR. Longitudinal changes in serum lipids among HIV-infected men on highly active antiretroviral therapy. HIV Med. 2007; 8:280-287. [PubMed: 17561873]

Ridker PM. C-reactive protein: a simple test to help predict risk of heart attack and stroke. Circulation. 2003; 108:81-85.

Ridker PM, Danielson E, Fonseca FA, Genest J, Gotto AM, Kastelein JJP, Koenig W, Libby P, Lorenzatti AJ, Macfadyen JG, Nordestgaard BG, Shephard J, Willerson JT, Glynn RJ. JUPITER Trial Study Group. Reduction in C-reactive protein and LDL cholesterol and cardiovascular event rates after initiation of rosuvastatin: a prospective study of the JUPITER trial. Lancet. 2009; 4:1175-1182. [PubMed: 19329177]

Rimland D, Guest JL, Hernández-Ramos I, Del Rio C, Le NA, Brown WV. Antiretroviral therapy in HIV-positive women is associated with increased apolipoproteins and total cholesterol. J Acquir Immune Defic Syndr. 2006; 42:307-313. [PubMed: 16770290]

Rose H, Woolley I, Hoy J, Dart A, Bryant B, Mijch A, Sviridov D. HIV infection and high-density lipoprotein: the effect of the disease vs the effect of treatment. Metabolism. 2006; 55:90-95. [PubMed: 16324925]

Santos RV, Coimbra CEA, Flowers NM, Silva JP. Intestinal parasitism in the Xavánte Indians, Central Brazil. Rev Inst Med Trop São Paulo. 1995; 37:145-148.

Seeman TE, Crimmins E, Huang M-H, Singer B, Bucur A, Gruenewald T, Berkman LF, Reuben DB. Cumulative biological risk and socioeconomic differences in mortality: MacArthur Studies of Successful Aging. Soc Sci \& Med. 2004; 58:1985-1997. [PubMed: 15020014]

Smith EM, Samadian S. Use of the erythrocyte sedimentation rate in the elderly. Br J Hosp Med. 1994; 51:394-397. [PubMed: 8081575]

Sox HC Jr, Liang MH. The erythrocyte sedimentation rate-guidelines for rational use. Ann Intern Med. 1986; 104:515-523. [PubMed: 3954279]

Stern N, Grosskopf I, Shapira I, Kisch E, Isaacov A, Limor R, Baz M, Leshem Y, Flatau E, Miller A, Greenman Y. Risk factor clustering in hypertensive patients: impact of the reports of NCEP-II and second joint task force on coronary prevention on JNC-VI guidelines. J Int Med. 2000; 248:203210.

Tanner, SN. University of Michigan, Ph.D. Dissertation. 2005. A population in transition: health, culture change, and intestinal parasitism among the Tsimane' of lowland Bolivia.

Tanner S, Leonard WR, McDade TW, Reyes-Garcia V, Godoy R, Huanca T. Influence of helminth infections on childhood nutritional status in lowland Bolivia. Am J Hum Biol. 2009; 21:651-656. [PubMed: 19402038]

Vadez V, Reyes-García V, Godoy RA, Apaza VL, Byron E, Huanca T, Leonard WR, Perez E, Wilkie D. Does integration to the market threaten agricultural diversity? Panel and cross-sectional data from a horticultural-foraging society in the Bolivian Amazon. Hum Ecol. 2004; 32:635-646. 
Vasunilashorn, S.; Finch, CE.; Kim, JK.; Winking, J.; Gurven, M.; Kaplan, H.; Crimmins, EM. Biomarkers of aging in two societies: The US and the Tsimane of Bolivia. 2010. Forthcoming.

Waldron I. Sex differences in human mortality: the role of genetic factors. Soc Sci Med. 1983; 17:321-333. [PubMed: 6344225]

Walker RS, Gurven M, Burger O, Hamilton MJ. The trade-off between number and size of offspring in humans and other primates. Proc R Soc B. 2008; 275:827-833.

Walter T, Olivares M, Pizarro F, Muñoz C. Iron, anemia, and infection. Nutr Rev. 1997; 55:111-124. [PubMed: 9197131]

Werner GT, Sareen DK. Serum cholesterol levels in the population of Punjab in north west India. Am J Clin Nutr. 1978; 31:1479-1483. [PubMed: 677088]

Wiedermann U, Stemberger H, Unfried E, Widhalm K, Kundi M, Altenriederer M, Savedra M, Wiedermann G. Intestinal worm burden and serum cholesterol or lipid concentration in a Shipibo population (Peru). Zentralbl Bakteriol. 1991; 275:279-286. [PubMed: 1930580]

Wilson PW, Anderson KM, Harris T, Kannel WB, Casteli WP. Determinants of change in total cholesterol and HDL-C with age: the Framingham study. J Gerontol A Biol Sci Med Sci. 1994; 49:252-257.

Zangerle R, Sarcletti M, Gallati H, Reibnegger G, Wachter H, Fuchs D. Decreased plasma concentrations of HDL cholesterol in HIV-infected individuals are associated with immune activation. J Acquir Immune Defic Syndr Hum Retrovirol. 1994; 7:1149-1156. 


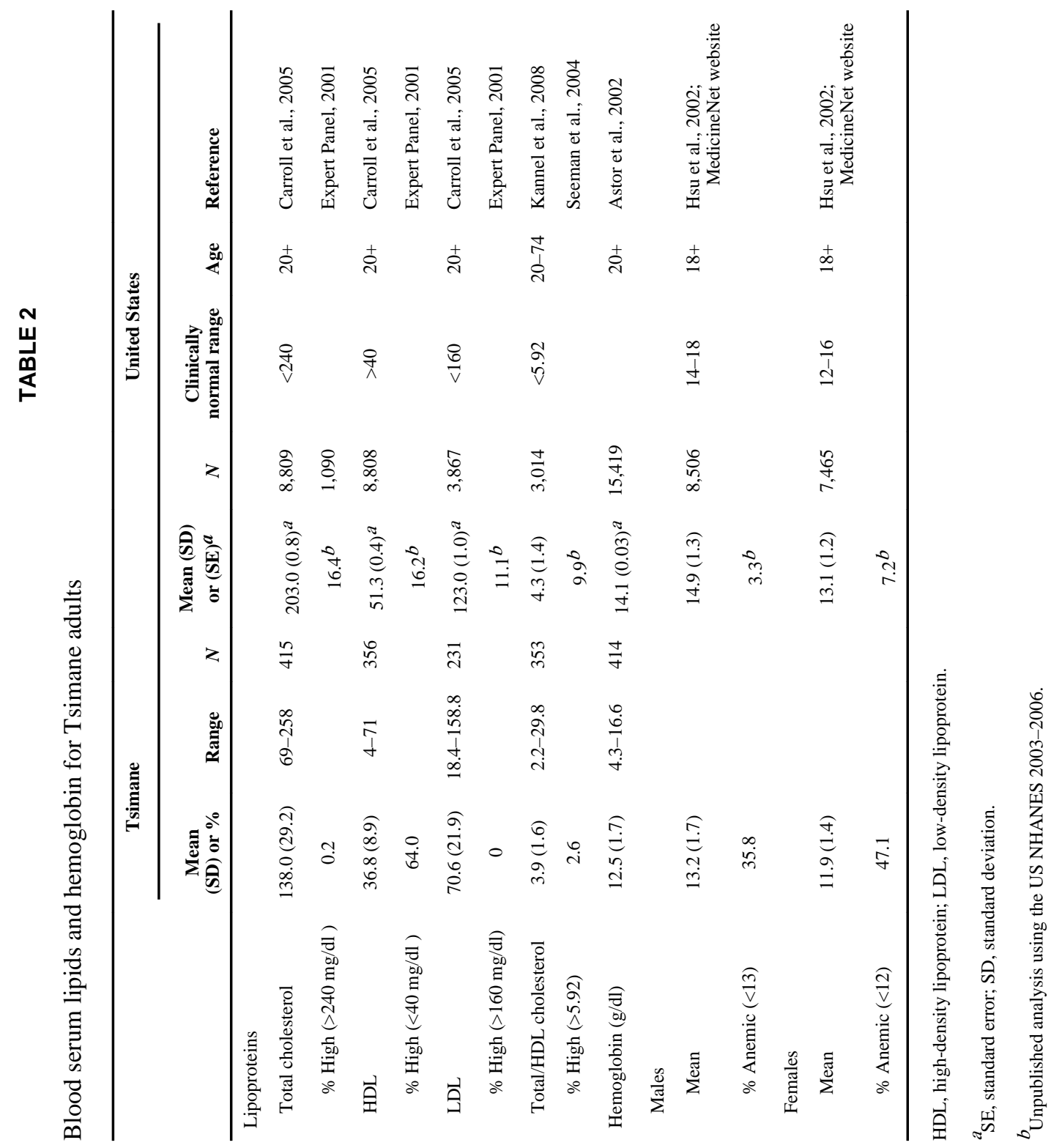




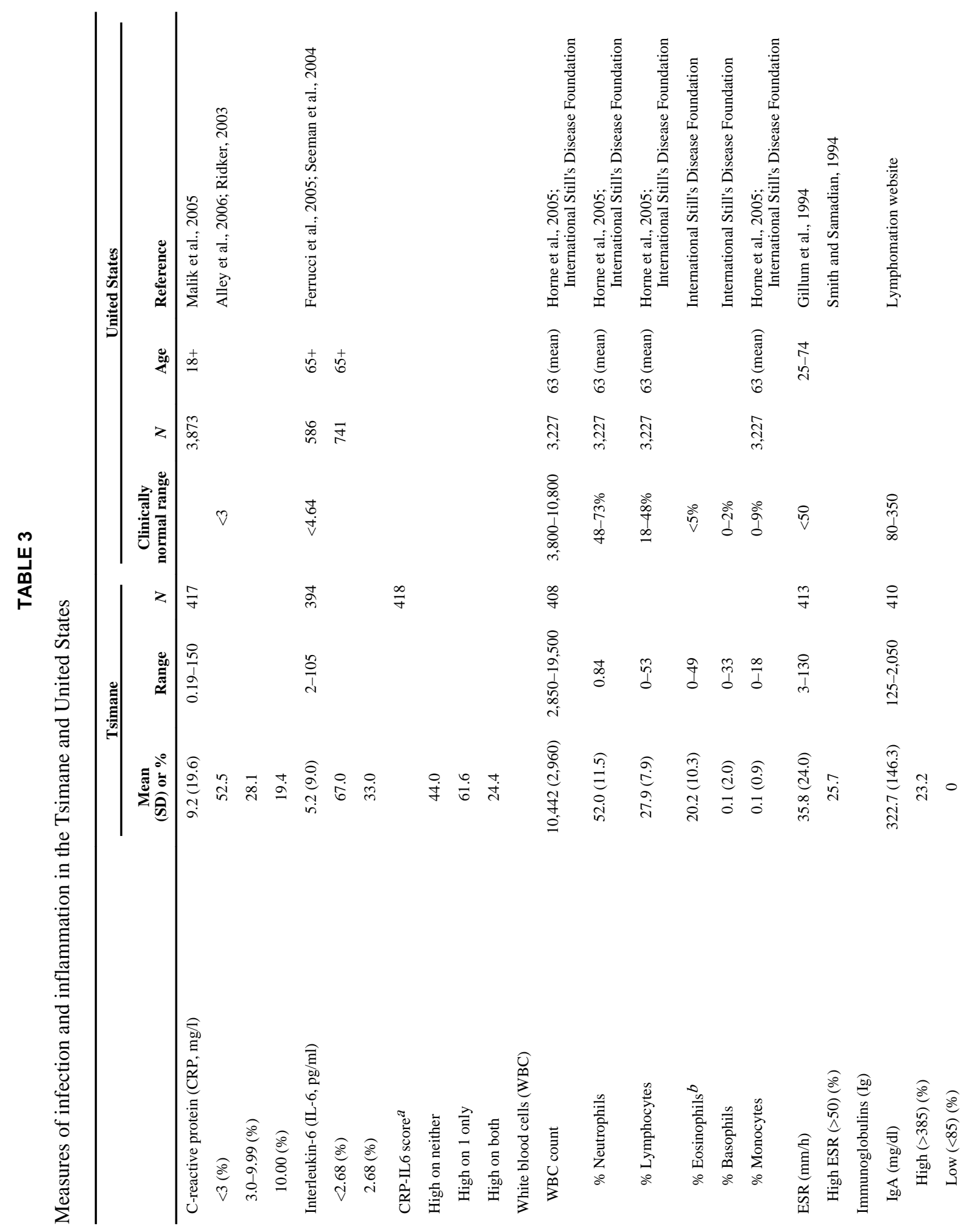




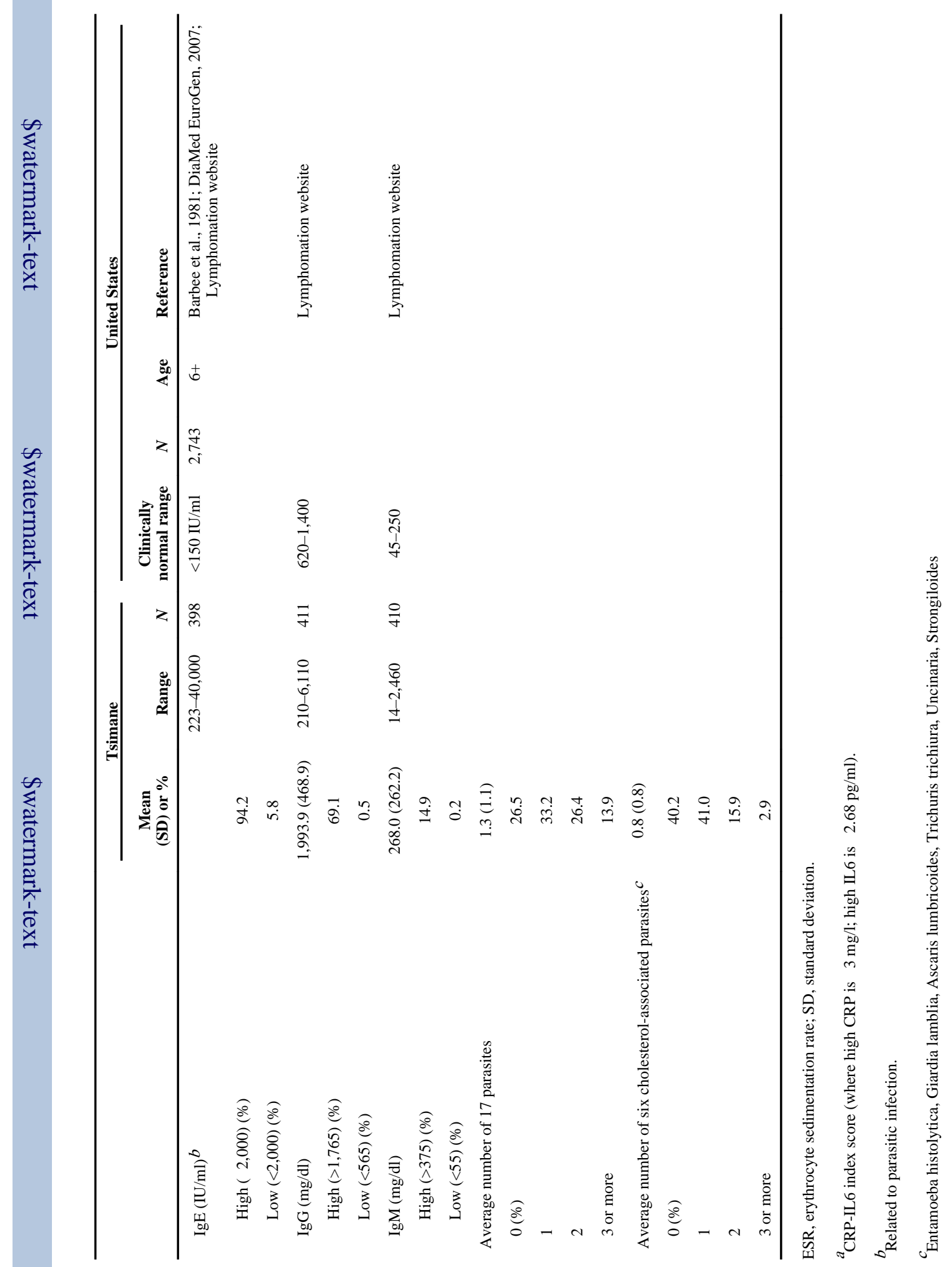




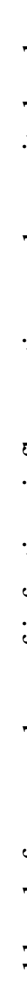

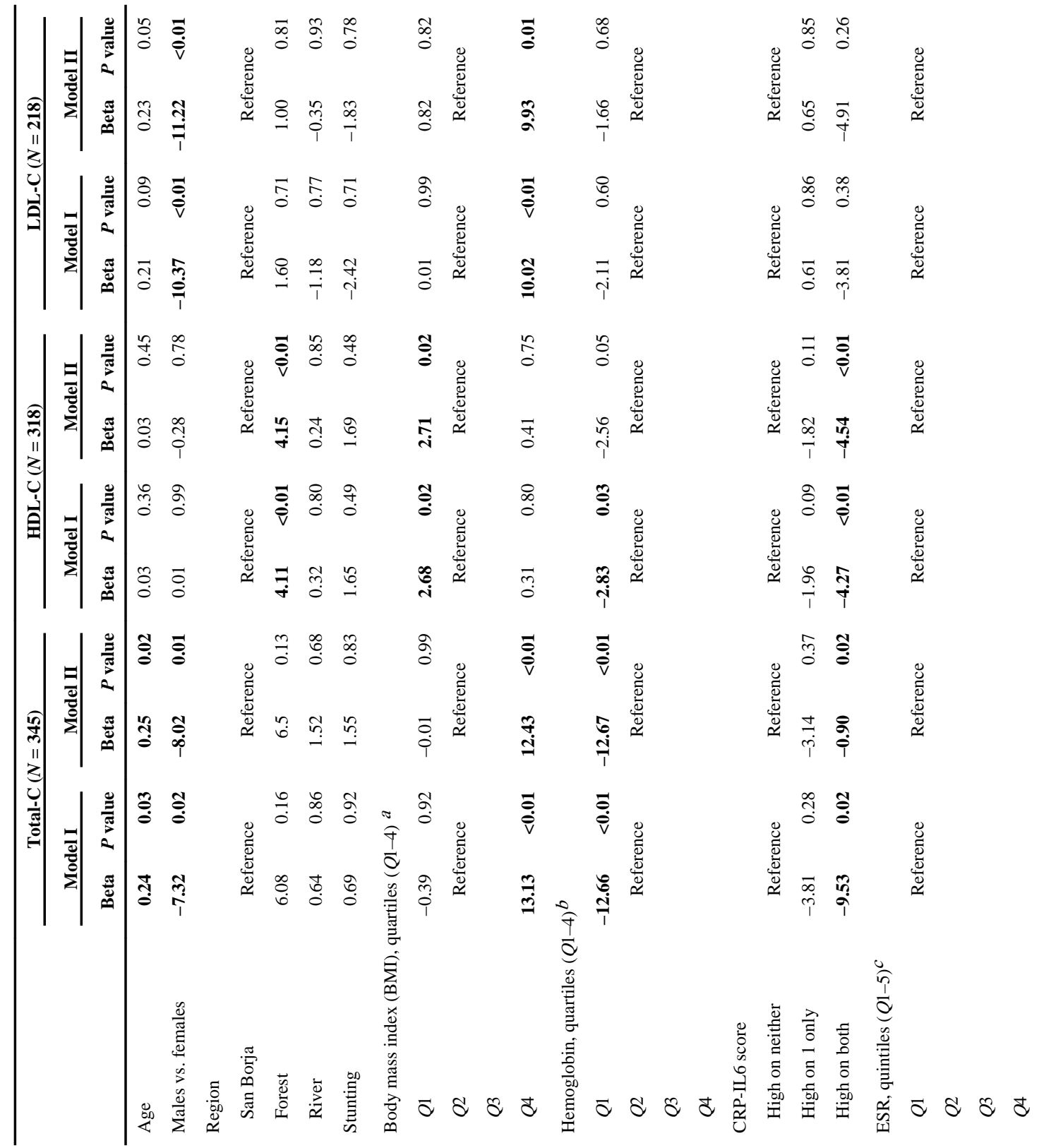




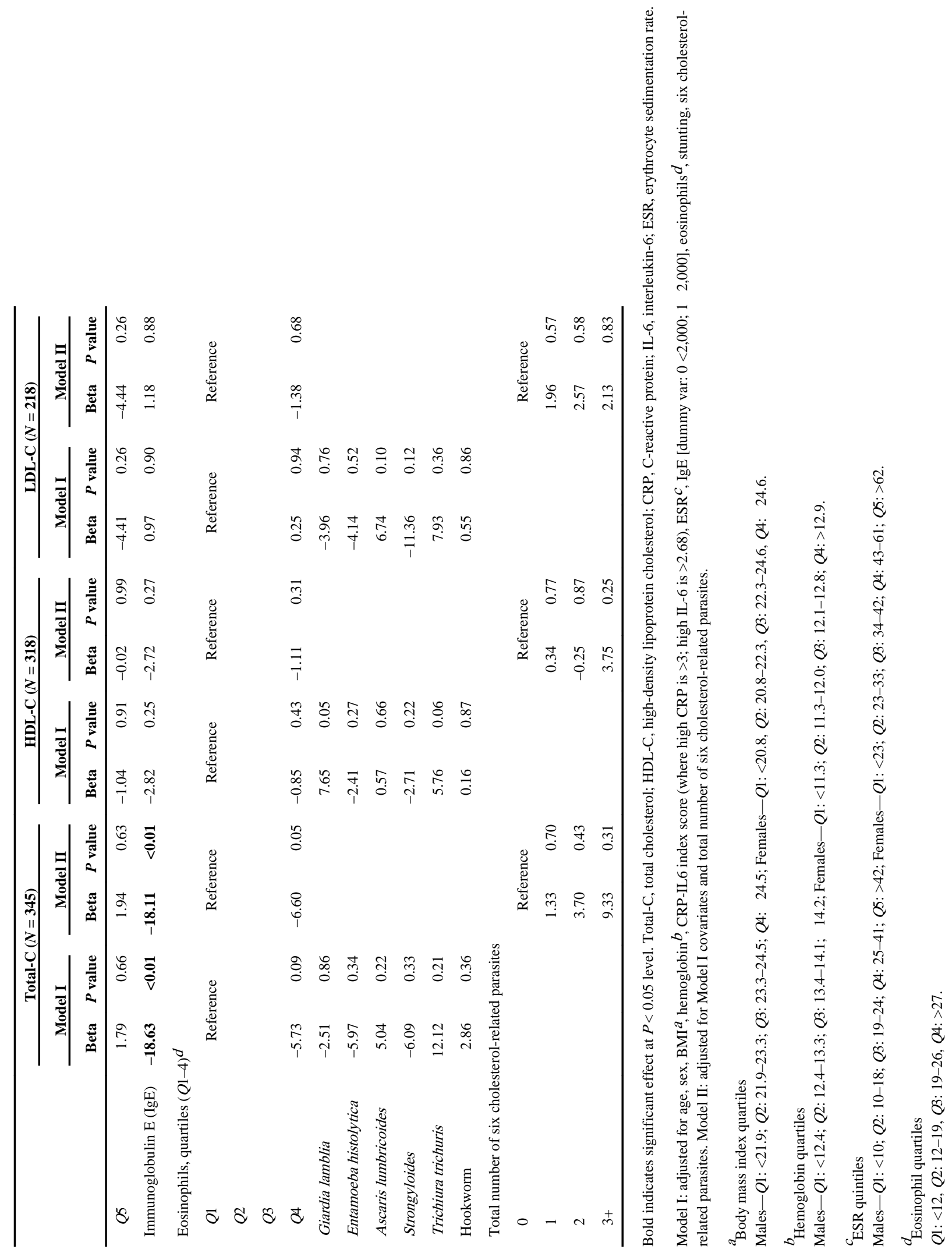

